\title{
СЛИЯНИЯ И ПОГЛОЩЕНИЯ БАНКОВ И КРЕДИТНЫХ ОРГАНИЗАЦИЙ
}

\author{
(c) 2019 Левченко Лариса Владимировна \\ кандидат экономических наук, доцент \\ Самарский государственный экономический университет, Россия, Самара \\ E-mail: lvls@mail.ru \\ (C) 2019 Городнов Валерий Андреевич \\ магистрант \\ Самарский государственный экономический университет, Россия, Самара
}

Статья посвящена изучению и анализу процессов слияния и поглощения банков и кредитных организаций в момент их появления и в современных экономических условиях России. В статье обосновывается вывод о том, что понятие «консолидация» на данный момент времени является одной из значимых проблем в современной финансовой среде России. Процесс слияния и поглощения в данный момент времени занимает практически одну из ведущих ролей в финансовом секторе российской экономики. Это обусловлено тем, что государство в последние годы напрямую пытается руководить всеми процессами консолидации и непосредственно принимает в них участие.

Ключевые слова: консолидация, слияния, поглощения, процесс, банковский сектор, рынок финансов, кредитные организации, банки, Российская Федерация.

РФ одна из последних развитых стран, которая очень поздно начала создавать банковские институты в сфере слияния и поглощения. Есть несколько причин, которые способствовали этомy.

Первой причиной является ряд российских законов, которые отвечали за управление банковским сектором и процессами слияния и поглощения банков. Второй причиной стало то, что РФ ни разу в своей истории не сталкивалась с таким понятием как консолидация и применение её на практике, которые применяются в банковской сфере. Третьим фактором является то, что вид собственности в банках РФ был очень закрытым и замутнённым.

В истории банковского дела РФ можно поэтапно выделить и разделить 5 процессов изменения банковского сектора в виде слияния и поглощения.

В первый этап входит отрезок времени с 1993 года по 1998 год, когда были созданы одни из первых фондов портфельных влияний денежных средств, которые в тоже время были как стратегическими, так и финансовыми инвесторами.

Ко второму этапу можно отнести отрезок времени с 1999 год по 2002 год. Рейдерские покушения в тот отрезок пути стали огромным затруднением для развития банковского сектора, также было проблемным присваивание себе не своих активов. Те года были обусловлены также тем, что не было нужных на то время законов и прав на присваивание себе собственности активов, что колоссально отличалось от уровня международного банковского дела.

Третий этап имел начало в 2003 году и продолжался до 2008 года. В эти года государственные структуры и государственные банки выступали в качестве покупателей частных кредитных организаций. Это был очень активный период слияния и поглощения в банковском секторе РФ. На эти действия банковский сектор РФ вынудила экспансия и влияние иностранного капитала, его часть в активах очень уверенно росла, а сам российский капитал, наоборот, убывал [1, с. 15].

2008 год уже можно отнести к началу четвёртого этапа. Это был период кризиса в РФ и в частности в банковской сфере. В сфере банковского сектора был сильно заметен спад деловой и финансовой активности, кардинально изменилось количество слияний и поглощений компаний. В РФ резко прекратили инвестировать иностранные банки, которые опасались проблем, связанных с экономикой. В то время маленькие частные банки прибегали к слиянию и поглощению для того чтобы хотя бы частично остаться на рынке.

Во время кризиса в РФ количество сделок по консолидации уменьшилось в несколько раз по сравнению с годами ранее. В то время ста- 
ли популярны сделки-санации. Это сделка при которой банк-санатор покупал банк с меньшей долей капитала по минимальной цене. Все эти сделки проходили при полном контроле РФ и государственных банков. Также в тот период банки и кредитные организации объединялись если они находились на одном уровне развития или же занимались одинаковой деятельностью и работали в одной и той же отрасли рынка. Этот метод был очень популярен так как за короткий срок и с наименьшими потерями денежных средств позволял снова захватывать ощутимые доли рынка.

Заключительный пятый этап начался в 2011 году и продолжается в РФ по сей день. Он кардинально отличается от других потому, что он направлен исключительно на улучшение функционирования банковского сектора. 2011 год ознаменовал собой приход новых правил и новых требований к величине капитала и объёму собственных средств кредитных организаций и банков. С 2013 года началась зачистка банковского сектора РФ, мелкие банки стали сливаться или присоединяться к более крупным игрокам на рынке или и вовсе лишались лицензии. В связи с этим частные лица больше не хотели связываться с частными компаниями и банками, юридические лица стали отзывать договора и подавали в суд на их расторжение. Это вызвало большой прирост количества консолидаций и ликвидаций. В 2013 году Банк РФ уменьшил с 20 до 10 процентов долю, которую могли приобретать без согласия с регулятором [4, с. 36].

В РФ было три актуальных направления рынка банковской консолидации. К первому можно отнести капитализацию и увеличение кредитных организаций. Вторым является слияние банков в группы и банковские холдинги. Третьим является уменьшение динамики консолидации в банковской среде.

Из-за того, что запросы к банкам стали более жёсткими, становится понятно, что государство хочет оставить на рынке только сильных игроков. На данный момент увеличивается интеграция банковского бизнеса вследствие образования банковских групп. Государство пытается подтолкнуть банки и кредитные организации к процессу слияния или поглощения. Банки должны будут иметь ввиду, что им придётся тратить большое количество денежных средств, чтобы остаться на рынке, но при этом они не должны забывать о том, что они должны выходить в при- быль [2, с. 28].

Вероятнее всего процессы консолидации имеют место быть в данный период после кризисного времени. Они помогают сформировать наиболее крепкий банковский сектор РФ. Что касается количества банков и количества кредитных организаций, то оно, исходя из всего выше перечисленного, будет уменьшаться до момента стабилизации экономики и установления сильных игроков на рынке.

По прогнозам экспертов, этот отрезок времени на банковском рынке является самым подходящим для улучшения позиций сильных и крупных банков. Однако, это влечет за собой то, что мелкие банки с низким уровнем капитала практически теряют все свои шансы на существование в современной банковской среде [3, c31].

Когда в РФ были промежутки спада экономики, большое количество банков начали чувствовать нехватку долгосрочных ресурсов. Чтобы привлечь денежные средства на счета своих банков, оставить прежним или увеличить количество сделок и операций и конкурентоспособность на рынке, банковские компании обязаны вносить перемены в свою деятельность. Банки начинают принимать всякого рода меры для уменьшения рисков во время кризиса, улучшения своего финансового положения и восстановления доверия клиентов. Сделки по слиянию и поглощению являются практически самой эффективной мерой, как отмечалось выше [6, с 50].

Чтобы получить синергетический эффект от слияния, банкам нужно применить процедуру консолидации: нужно увеличить капитализацию, существенно повысить количество клиентов в базах и расширить географию присутствия, найти новые финансы, и укрепить свою позицию на рынке, они должны стать конкурентоспособными и устойчивыми.

Также рассмотрение исследования рынка слияний и поглощений за период с 2006 года по 2019 год показывает, что самый максимум сделок, как за счет количества, так и за счет денежной составляющей было совершено с 2007 года по 2009 год. В этот промежуток времени доля иностранного капитала в активах российских банков беспрепятственно поднималась. В качестве зарубежных инвесторов выступали такие страны как: Кипр, Швеция, Франция, США. Если взглянуть на статистику, которую подготовило «Национальное Рейтинговое Агентство», с 2006 
года по 2016 год на рынке банковского сектора было завершено 196 сделок слияний и поглощений, их объём был приблизительно равен 19.5 млрд. долл. США [5, с 30].

На направления и тенденции слияний и поглощений в банковском секторе кардинально повлиял мировой финансовый кризис 20082010 годов. Иностранные банки встретили на своём пути большие экономические проблемы и решили остановить экспансию на рынок РФ, что повлекло за собой прекращение притока инвестиций из-за рубежа. Самой важной целью для структур РФ стало удержание финансовой стабильности в непростых условиях кризиса.

В частности, консолидация стала побуждением к восстановлению финансовой устойчивости для банков которые были устойчивее. Банки, которые были менее устойчивы были вынуждены применять санацию либо просить помощи у государства. Таким образом, большая доля сделок в тот кризисный отрезок времени носила характер поглощения. Банки-санаторы поглощали банки с большими проблемами и в банковскую сферу пришло выражение «сделкисанации». Редкими в то время были сделки, когда один крупный банк не смог поглотить другой с большими проблемами. Например, РЖД совместно с авиакомпанией «ALROSA» не сумели осуществить санацию отделения «KIT FINANCE», впрочем, также, как и «NACIONALNII REZERVNI BANK» не смог поглотить «ROSSIISKI KAPITAL», который был в то время очень проблемным банком.

Вероятнее всего процессы консолидации имеют место быть и в послекризисный период времени. Они помогают сформировать более крепкий банковский сектор РФ. Что касается количества банков и кредитных организаций, то оно, исходя из всего вышеперечисленного, будет уменьшаться до момента стабилизации экономики и установления сильных игроков на рынке $[8$, c. 773].

По прогнозам экспертов, этот отрезок времени на банковском рынке является самым подходящим для улучшения позиций сильных и крупных банков [10, с.15]. Однако это влечет за собой то, что мелкие банки с низким уровнем капитала практически теряют все свои шансы на существование в современной банковской среде из-за слияний, а даже в основном из-за поглощений.

134\%, именно на столько выросла сумма операций слияния и поглощения в 2018 года, в которых принимали участие банки РФ. Это самый большой рост данных сделок за последние годы, однако и число операций, как говорят аналитики Томсон Реутерс, сейчас самое низкое -499 операций.

Несмотря на возросший объём операций консолидации в целом, их число в 2018 года сократилось на 25\% по сравнению с 2017 годом. Чаще всего в этих операциях принимал участие «ВТБ Капиталл», он забрал себе 18,2\% доли рынка.

Самой весомой операцией в 2018 году с участием банка РФ стала продажа Сбербанком «Денизбанк», на что не малую роль оказали западные санкции. Данная операция прошла в мае 2018 г., а её сумма составила 3,2 млрд. долларов США.

Банк ВТБ также смог отличиться в 2018 году. Это была вторая по дороговизне покупка самого большого ретейлера РФ «Магнита». Эти акции банк оценил в 2,45 млрд. долларов США.

В 2018 году ещё одной громкой продажей стала доля в компании «Норникель» за 1,5 млрд. долларов США. Её в марте провели ЮК «Русал» и «Интеррос» [9].

\section{Библиографический список}

1. Воронова Н.С. слияния и присоединения в банковском секторе России / Н.с. Воронова, О.с. Мирошниченко // Экономика. Бизнес. Банки. - 2016. - № 4 (17). - с. 8-23.

2. Данилина Е.В. Тенденции развития мирового рынка слияний и поглощений в банковской сфере / Е.В. Данилина // Банковские услуги. - 2015. - № 6. - с. 28-32.

3. Диденко В.Ю. Консолидация банковского сектора в форме слияний и поглощений / В.Ю. Диденко // Финансовая аналитика: проблемы и решения.-2016.- № 17 (299). - с. $28-41$.

4. Карминский А.М. Особенности оценки стоимости сделок слияний и поглощений в банковском секторе / А.М. Карминский, Э.А. Фролова // Финансовая аналитика: проблемы и решения. - 2016. - № 45 (327).c. $28-50$.

5. Копий С.А. Тенденции на рынке банковских слияний (поглощений) и особенности их проявления в России в условиях кризиса / с.А. Копий // Научный обозреватель. - 2016. - № 3.- c. 30-32. 
6. Мгерян М.А. Тенденции слияний и поглощений банков в России / М.А. Мгерян, Е. В. Репина // Заметки ученого. - 2015. - № 6-1 (6). - с. 50-53.

7. Отчет о развитии банковского сектора и банковского надзора / [Электронный ресурс].- Режим доступа: URL: http://www.Cbr.ru/publ/? PrtId=nadzor/.

8. Плеханов И.А. Мотивы слияний и поглощений коммерческих банков / И.А. Плеханов, А.А. Коновальчук // Экономика и социум. - 2016. - № 2 (21). - с. 772-775.

9. Рейтинговое Национальное агентство «Рынок банковских слияний и поглощений: актуальное состояние и перспективы». [Электронный ресурс]: база данных. - Режим доступа: http://www.ra- national.ru/.

10. Рязанова О.Е., Левченко Л.В. Инвестиционный климат как условие для развития инновационной экономики// Экономические науки. 2014.№ 114. С. 14-28. 